\title{
Sebaran dan Kondisi Karang Batu di Perairan Kecamatan Wori, Sulawesi Utara
}

\author{
Distribution and Condition of Hard Coral At Wori District Waters, North Sulawesi
}

Jemmy Souhoka

UPT. Loka Konservasi Biota Laut LIPI Bitung

Jln. Tandurusa No.1 Bitung, Sulawesi Utara

E-mail:koral_js@yahoo.com

\begin{abstract}
Hard or stony coral is one important component to structure the coral reef ecosystem and play a significant role for its marine life and its surrounding. Therefore, the condition of reef ecosystem needs to be maintained. Research on stony coral condition and distribution in waters of Wori Village, North Sulawesi, was conducted in April 2008. Line Intercept Transect was applied to assess the coral condition. A $50 \mathrm{~m}$ line transect was set on the 5 - $7 \mathrm{~m}$ depth horizontally coastal line with assumption that in this depth, coral growth well. The results of this study show that the condition of coral was between 1,00 and $53,44 \%$ indicating the condition ranged from bad to good category. Stony coral distribution was found up to $20 \mathrm{~m}$ depth, with the highest diversity and evennes indices were 1,06 at station 3 , and 0,56 at station 4 , respectively. Numbers of stony coral were 99 species belonging to 40 genus and 14 families.
\end{abstract}

Key words: Distribution, condition, hard coral, Wori District

\begin{abstract}
Abstrak
Karang batu merupakan salah satu component utama pembentuk ekosistem terumbu karang dan mempunyai peranan yang sangat penting dalam memberikan sumbangsih bagi organisme yang ada di sekitarnya maupun ada di dalamnya. Dengan pentingnya ekosistem ini bagi organisme, maka kondisi suatu ekosistem terumbu karang perlu diperhatikan. Penelitian mengenai kondisi karang batu dan sebarannya di perairan Desa Wori, Sulawesi Utara dilakukan pada bulan April 2008. Metode yang digunakan dalam penelitian ini yaitu metode line transek dengan panjang transek $50 \mathrm{~m}$ yang diletakan secara horisontal garis pantai pada kedalaman 5-7 m dengan asumsi bahwa pada kedalaman ini pertumbuhan karang batu cukup padat. Hasil pengamatan menunjukkan bahwa kondisi karang batu berkisar antara 1,00-53,44\% yang termasuk dalam kategori jelek sampai baik. Distribusi karang batu sampai pada kedalaman $20 \mathrm{~m}$, dengan indeks keragaman jenis tertinggi 1,06 yang ditemukan di Stasiun 3 dan indeks kemerataan jenis tertinggi sebesar 0,56 yang ditemukan di Stasiun 4. Jumlah jenis karang batu yang ditemukan sebanyak 99 jenis yang termasuk dalam 40 marga dan 14 suku.
\end{abstract}

Kata kunci: Sebaran, kondisi, karang batu, Kecamatan Wori

Diterima: 30 Maret 2009, disetujui: 24 Maret 2010

\section{Pendahuluan}

Karang (coral) mempunyai beberapa arti, tetapi biasanya merupakan nama umum yang diberikan kepada ordo Scleractinia, yang semua anggotanya mempunyai skeleton batu kapur keras (Sudiarta, 1995). Karang batu merupakan salah satu komponen pembentuk ekosistem terumbu karang. Keberadaan karang batu pada suatu perairan akan memberikan dampak yang menguntungkan bagi biota yang ada di dalam ekosistem terumbu karang maupun yang berasosiasi dengannya. Fungsi karang batu secara umum mempunyai peranan sebagai tempat mencari makan, membesarkan diri, dan berlindung bagi organisme-organisme di sekitarnya. Di samping itu karang batu merupakan benteng pertahanan dari empasan ombak (Odum, 1971) dan sekaligus mengurangi terjadinya abrasi. 
Sebaran karang batu di dalam suatu perairan tidak terlepas dari beberapa faktor utama antara lain kedalaman air laut, aksi gelombang, cahaya, sedimen, suhu, bathimetri dan pola sikulasi samudera (Veron, 1986). Indonesia merupakan salah satu kepulauan yang paling kaya jenis karang batunya (Ditlev, 1980).

Wori merupakan salah satu kecamatan yang masuk daerah administratif Kabupaten Minahasa, Propinsi Sulawesi Utara. Kecamatan Wori memiliki beberapa desa nelayan dan pulaupulau kecil antara lain Pulau Nain dan Pulau Mantehage. Sebagian besar perairan pantainya memiliki tiga ekosistem yaitu ekosistem bakau, ekosistem lamun dan ekosistem terumbu karang. Informasi tentang kondisi karang batu di Kecamatan Wori belum banyak terungkap. Dengan demikian, penelitian ini dilakukan untuk melihat sebaran dan kondisi karang batu di lokasi perairan Kecamatan Wori, dengan harapan hasilnya dapat dijadikan sebagai bahan pertimbangan dalam pengelolaan wilayah pesisir, khususnya pantai kecamatan Wori.

\section{Metode Penelitian}

Penelitian sebaran dan kondisi karang batu di perairan Kecamatan Wori, Kabupaten Minahasa telah dilakukan pada bulan April 2008 di empat stasiun pengamatan (Gambar 1). Penentuan empat stasiun pengamatan terumbu karang di Kecamatan Wori ini didasarkan atas hasil citra yang menunjukkan lokasi-lokasi tersebut mempunyai luasan terumbu karang yang cukup luas, sehingga dapat dijadikan sebagai areal pengamatan kondisi karang batu.

Penelitian ini menggunakan metode transek garis (line transecd method) yang dikemukakan oleh English et al., (1997). Teknis pengukuran transek garis pada areal terumbu karang dilakukan dengan membentangkan meteran rol sepanjang $50 \mathrm{~m}$ sejajar garis pantai pada kedalaman antara 6-7 meter dengan asumsi kepadatan karang batu dan komponen lainnya pada kedalaman tersebut cukup padat. Setiap komponen yang dilewati garis transek dicatat dengan mengikuti kode morfologi bentik sebagaimana yang dikemukakan oleh Australian Institute of Marine Science (UNEP, 1993). Identifikasi jenis karang batu dilakukan langsung di lapangan, sedangkan jenis karang batu yang belum diketahui namanya diambil sampel dan diidentifikasi di UPT. Loka Konservasi Biota Laut - LIPI Bitung, dengan mengacuh pada buku identifikasi dari Veron (1986); Moll dan Moka (1986); Koh dan Chou (1989); Allen dan Steene (2002); Suharsono (2008). Data komposisi jenis karang batu dilakukan secara bebas pada kedalaman 1-15 m. Data yang diperoleh dianalisis untuk menentukan persentase tutupan dan sebaran karang batu, indeks keanekaragaman jenis $(\mathrm{H})$ dan indeks kemerataan jenis (j) (Odum, 1971), dengan rumus sebagai berikut:

\section{Persentase Tutupan}

$$
\text { PT = -------------------- } \text { x } 100 \%
$$

Indeks Keanekaragaman Jenis (H) (ShannonWeaner)

$$
\mathrm{H}=-\sum(\mathrm{ni} / \mathrm{N}) \log (\mathrm{ni} / \mathrm{N})
$$

Indeks Kemerataan Jenis (j) (Pielou, 1966)

$$
\mathrm{j}=\mathrm{H} / \log \mathrm{S}
$$

Keterangan : $\mathrm{PT}=$ persentase tutupan

$\mathrm{H}=$ nilai keanekaragaman jenis

$\mathrm{ni}=$ jumlah persentase tutupan jenis

$\mathrm{N}=$ jumlah total persentase tutupan

$\mathrm{j}=$ nilai kemerataan jenis

$\mathrm{S}=$ total jumlah jenis

\section{Hasil dan Pembahasan}

\section{Deskripsi Lokasi Penelitian}

\section{Stasiun 1 (Bolung)}

Lokasi pengamatan berhadapan dengan Pulau Siladen, Pulau Bunaken dan Pulau Mintehage. Bagian daratannya merupakan daerah permukiman penduduk yang cukup padat, disertai dengan pertumbuhan bakau yang tumbuh cukup lebat. Daerah rataan terumbu (reef flat) yang mempunyai panjang lintasan 225 m. Substrat dasar perairan berupa pasir, pasir agak berlumpur, patahan karang dan karang mati (Gambar 2). Kondisi perairan pada saat pengamatan mempunyai pola arus sedang, kecerahan agak rendah dan proses sedimentasi cukup tinggi. Lokasi ini dijumpai 20 ekor Acanthaster plancii yang merupakan salah satu biota pemakan karang batu. Jenis karang batu 
yang dominan adalah Porites nigrecens, $P$. lutea, P. lobata dan Favites sp.

\section{Stasiun 2 (Buhias)}

Pengamatan dilakukan pada salah satu sisi Pulau Mintahage yaitu di pantai Desa Buhias. Lokasi ini mempunyai 2 zona rataan (reef flat) yang terdiri dari zona rataan pertama terletak pada bagian pantai dengan panjang lintasan 150 meter dari garis pantai dan rataan kedua berada setelah goba (lagoon) pada kedalaman antara 5-7 m. Panjang lintasan zona rataan kedua yaitu $175 \mathrm{~m}$ sampai pada daerah tubir yang merupakan daerah terumbu karang (Gambar 3). Jenis karang batu yang dominan adalah Millepora sp, Seriatophora caliendrum, Porites nigrecens, Favites sp, Fungia sp dan Acropora sp.

\section{Stasiun 3 (Tioho)}

Lokasi ini merupakan sebuah desa yang cukup padat jumlah penduduknya dan pada bagian pantainya dijumpai tumbuhan bakau yang cukup padat bahkan pertumbuhannya ada yang menjulur ke laut $\pm 40 \mathrm{~m}$. Kondisi perairan pada saat pengamatan sedikit berarus dan kecerahan sedang, dan terlihat adanya sedimen yang melayang di dalam perairan. Zona rataan (reef flat) mempunyai panjang lintasan sejauh $225 \mathrm{~m}$ dari garis pantai. Selanjutnya, bentuk dasar perairan berbentuk agak miring (Gambar 4). Substrat dasar perairan berupa pasir, patahan karang dan karang mati. Jenis karang batu yang dominan adalah Porites nigrecens, Porites lutea, Porites lobata, Fungia sp, Acropora sp dan Favites sp.

\section{Stasiun 4 Desa Wori}

Pengamatan di lokasi Desa Wori dilakukan pada areal yang berjarak $\pm 2 \mathrm{~km}$ kearah pesisir utara. Pengamatan kondisi terumbu karang dilakukan pada jarak $\pm 200 \mathrm{~m}$ dari garis pantai ke arah laut terbuka. Kondisi perairan pada saat pengamatan mempunyai pola arus yang tidak terlalu kuat dan kecerahan agak rendah di mana sedimentasi terlihat cukup tinggi. Bentuk dasar perairan mempunyai zona rataan (reef flat) yang cukup panjang $(200 \mathrm{~m})$. Selanjutnya bentuk dasar perairan agak miring $(10 \mathrm{~m})$ dan curam (drop out) sampai kedalaman $20 \mathrm{~m}$ (Gambar 5). Substrat dasar perairan berupa patahan karang dan karang mati. Karang batu yang dominan yaitu Acropora palifera, Porites nigrecens dan Pocillopora verrucosa.

\section{Sebaran Karang Batu}

Pertumbuhan karang batu di semua lokasi pengamatan pada umumnya, terkosentrasi pada dasar perairan yang agak miring sampai curam. Dari hasil identifikasi jenis karang batu yang dilakukan secara bebas mulai dari kedalaman 0,5 m sampai kedalaman $25 \mathrm{~m}$ (Tabel 1) ditemukan 99 jenis karang batu yang termasuk dalam 40 marga dan 14 suku.

Jumlah jenis karang batu tertinggi dijumpai di Stasiun 3 sebesar 89 jenis yang mewakili 38 marga dan 13 suku, sedangkan yang terendah dijumpai di Stasiun 1 sebesar 27 jenis yang mewakili 16 marga dan 8 suku. Tinggi dan rendahnya jumlah jenis karang batu di perairan Kecamatan Wori mempunyai hubungan dengan parameter fisik perairan seperti salinitas, temperatur dan kecerahan. Hasil pengukuran menunjukkan nilai salinitas rerata yang diperoleh sebesar $30 \%$, temperatur $29^{\circ} \mathrm{C}$, dan kecerahan $15 \mathrm{~m}$. Besarnya nilai parameter fisik air laut yang diperoleh ini mempunyai toleransi terhadap pertumbuhn karang batu, sebagaimana yang diungkapkan oleh Smith (1948) dalam Sukarno et al., (1981) yang menyatakan bahwa kosentrasi pertumbuhan karang batu pada umumnya berada pada kisaran salinitas antara 25-40\%. Salm dan Clark (1989) mengungkapkan bahwa terumbu karang merupakan ekosistem laut dangkal daerah tropis yang perkembangannya terbaik pada suhu antara $25-29^{\circ} \mathrm{C}$. Hasil pengukuran temperatur di lokasi ini mempunyai nilai terendah $28^{\circ} \mathrm{C}$ dan tertinggi $30^{\circ} \mathrm{C}$ yang dijumpai di Stasiun 3 .

Pertumbuhan karang batu di seluruh stasiun pengamatan Kecamatan Wori, pada umumnya terkosentrasi pada jarak di atas $200 \mathrm{~m}$ dari garis pantai dengan bentuk dasar agak miring dengan kedalaman $3 \mathrm{~m}$ sampai dengan bentuk dasar perairan yang agak curam dengan kedalaman sampai $20 \mathrm{~m}$. Sebaran karang batu yang cukup jauh dari garis pantai ini menjamin pertumbuhannya agak lebih baik karena tidak dipengaruhi oleh aktivitas manusia yang terjadi di daerah pesisir pantai. 


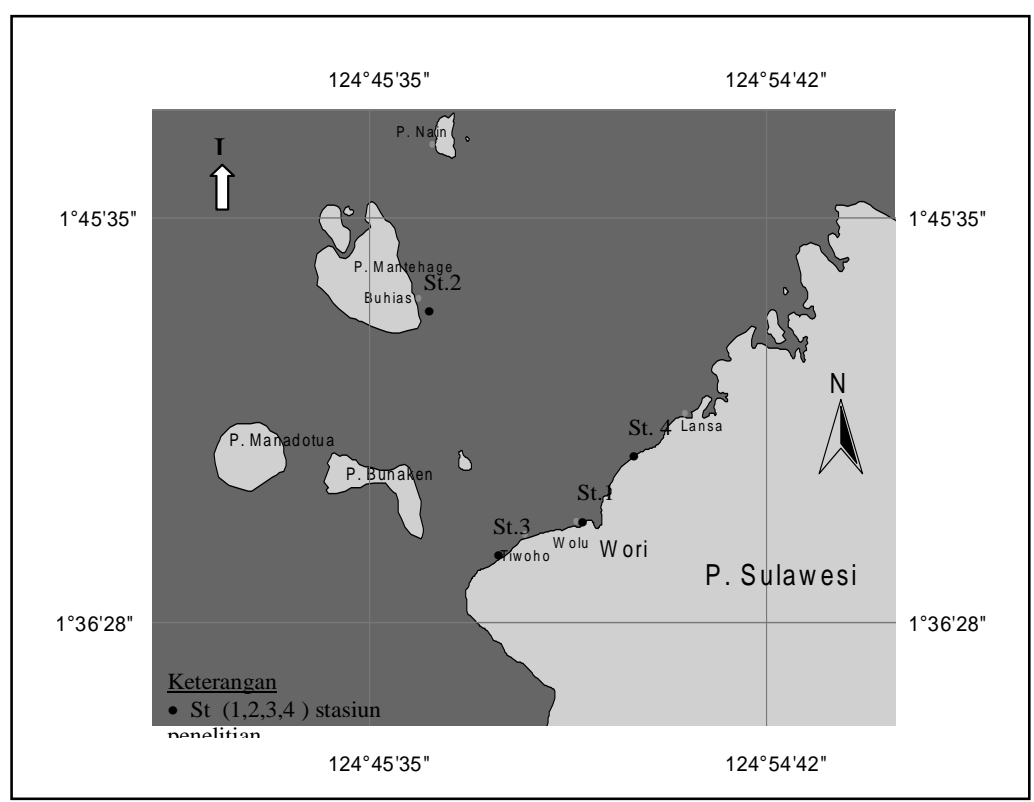

Gambar 1. Peta lokasi penelitian di perairan Kecamatan Wori, Sulawesi Utara.

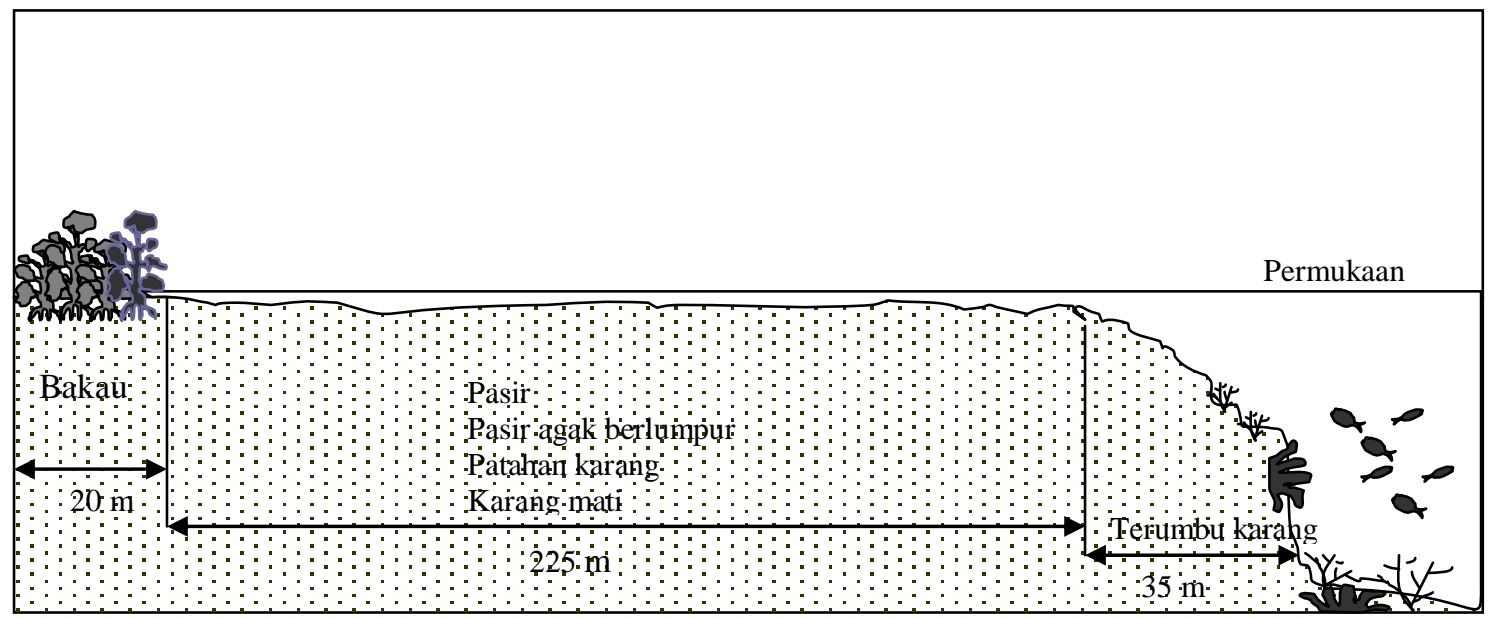

Gambar 2. Bentuk dasar perairan pada Stasiun 1 di Kecamatan Wori, April 2008.

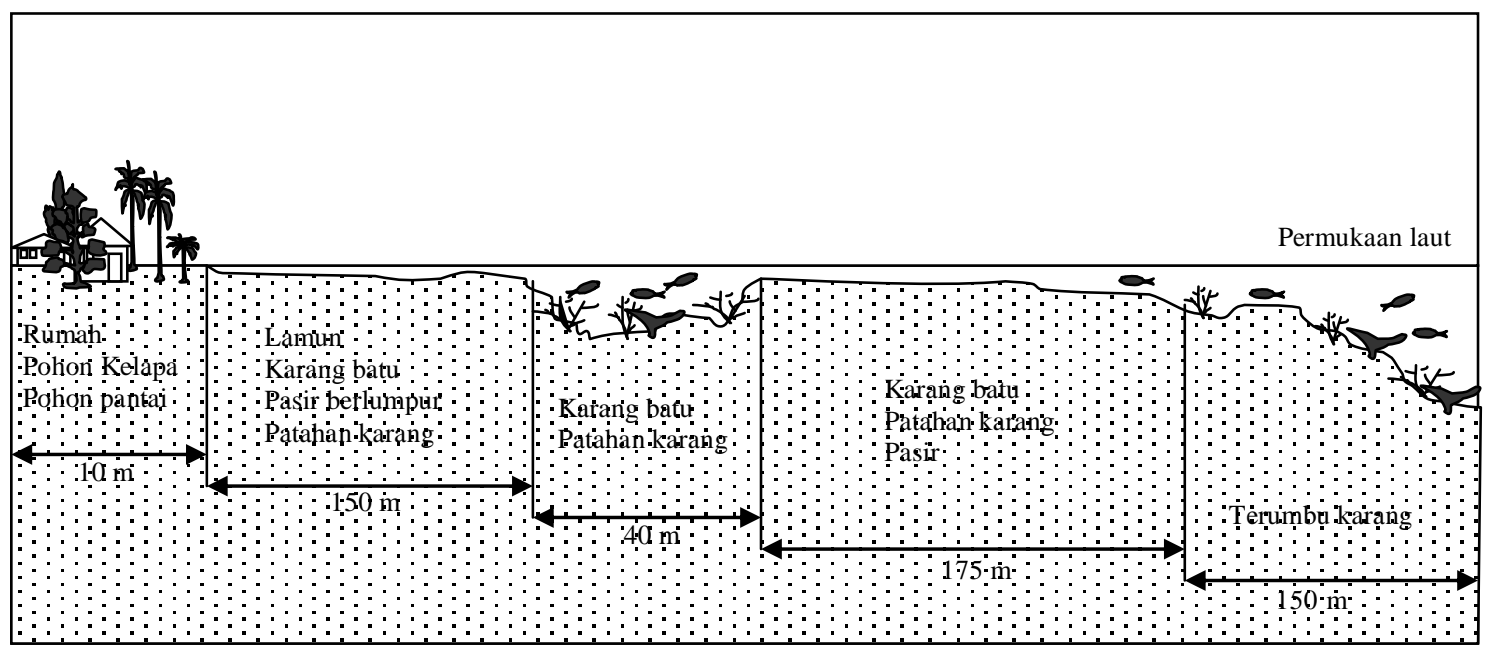

Gambar 3. Bentuk dasar perairan pada Stasiun 2 di Kecamatan Wori, April 2008. 


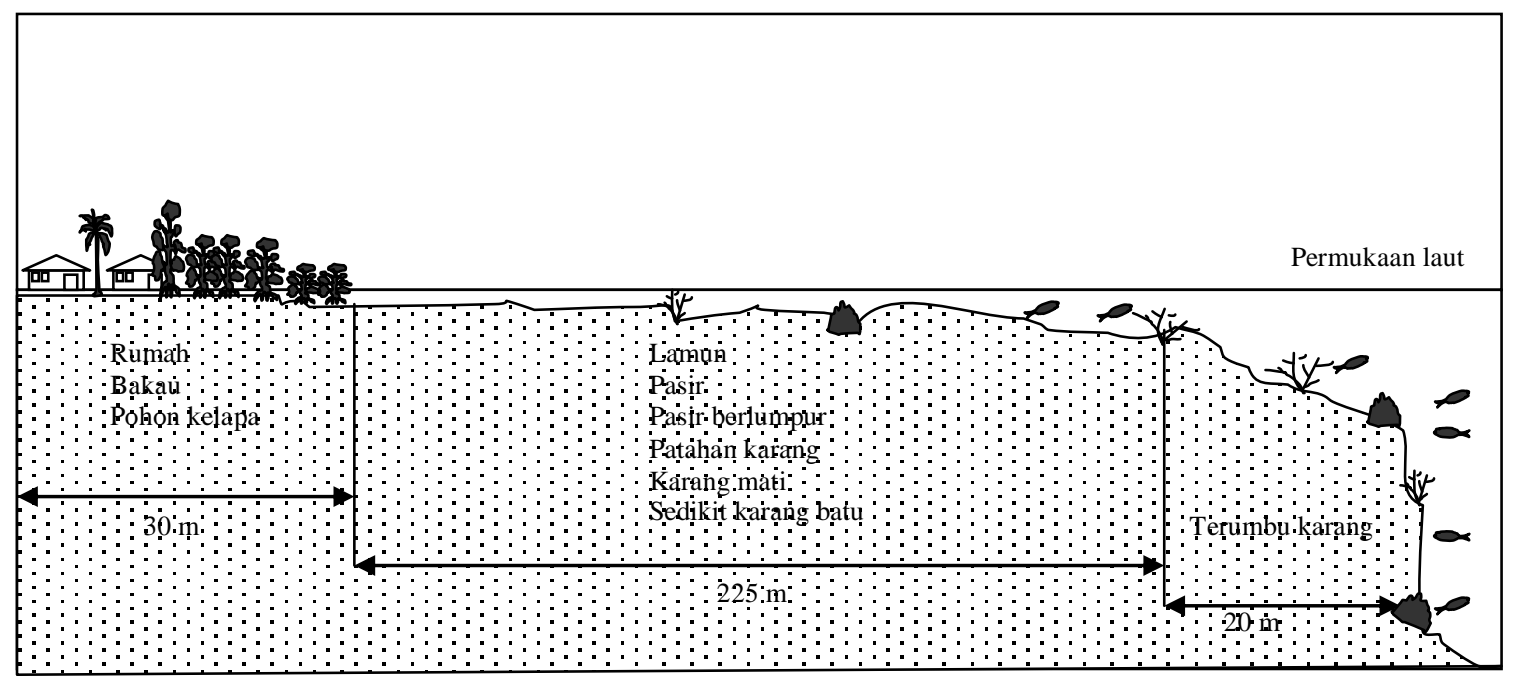

Gambar 4. Bentuk dasar perairan pada Stasiun 3 di Kecamatan Wori, April 2008.

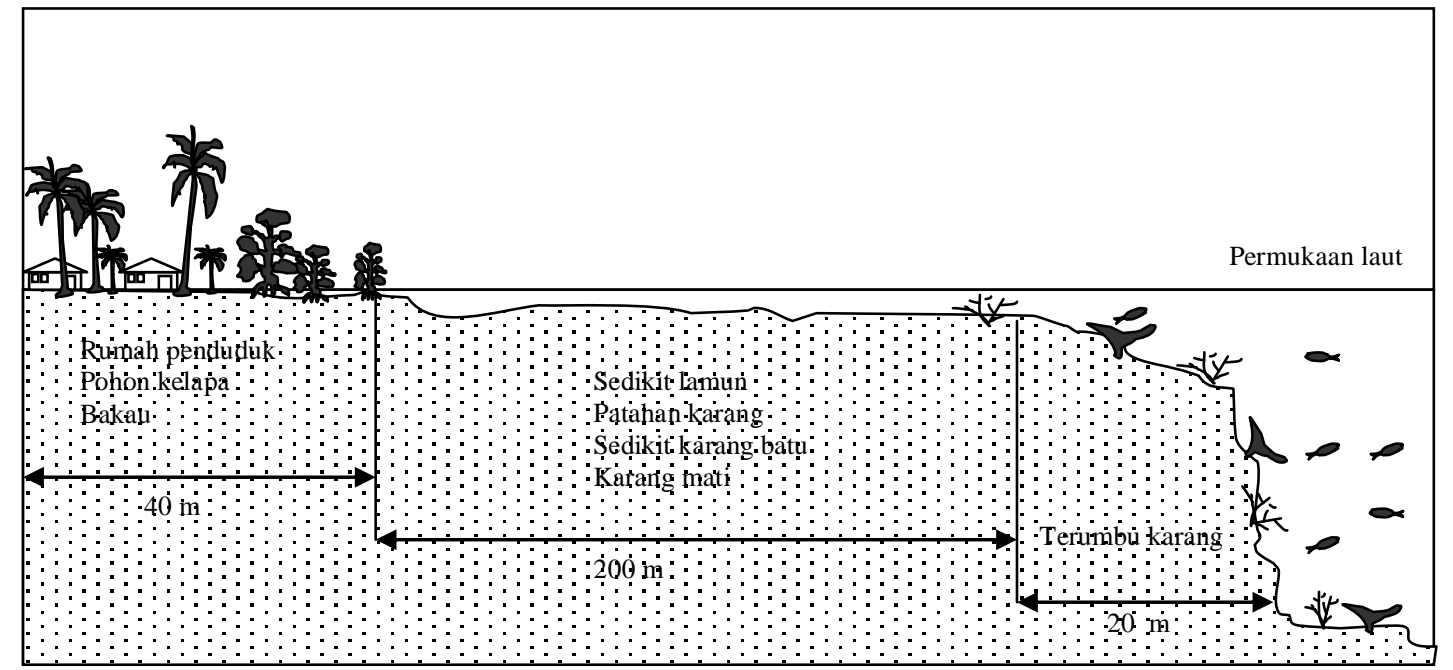

Gambar 5. Bentuk dasar perairan pada Stasiun 4 di Kecamatan Wori, April 2008.

Tabel 1. Komposisi jenis karang batu pada lokasi penelitian di Kecamatan Wori, April 2008.

\begin{tabular}{|c|c|c|c|c|}
\hline \multirow{2}{*}{ Suku / Jenis Karang Batu } & \multicolumn{4}{|c|}{ Lokasi Pengamatan } \\
\hline & Stasiun 1 & Stasiun 2 & Stasiun 3 & Stasiun 4 \\
\hline \multicolumn{5}{|l|}{ I. POCILLOPORIDAE } \\
\hline Pocilopora damicornis & + & + & + & - \\
\hline P. verrucosa & + & + & + & - \\
\hline P. meandrina & - & - & + & - \\
\hline Seriatopora hystrix & + & + & + & - \\
\hline Seriatopora caliendrum & - & + & + & + \\
\hline Stylophora pistillata & + & - & - & + \\
\hline \multicolumn{5}{|l|}{ II. ACROPORIDAE } \\
\hline Montipora monasteriata & - & - & + & - \\
\hline M. tuberculosa & - & + & + & + \\
\hline M. hoffmeisteri & - & - & + & + \\
\hline M. spongodes & - & - & + & - \\
\hline M. undata & - & - & + & + \\
\hline M. squmosa & - & + & - & - \\
\hline M. venosa & - & + & + & - \\
\hline Anacropora forbesi & - & + & + & - \\
\hline
\end{tabular}




\begin{tabular}{|c|c|c|c|c|}
\hline \multirow{2}{*}{ Suku / Jenis Karang Batu } & \multicolumn{4}{|c|}{ Lokasi Pengamatan } \\
\hline & Stasiun 1 & Stasiun 2 & Stasiun 3 & Stasiun 4 \\
\hline Acropora palifera & + & + & + & + \\
\hline A. gemmifera & + & - & + & - \\
\hline A. nobilis & + & - & + & + \\
\hline A. formosa & - & - & + & - \\
\hline A. vaughani & - & + & - & + \\
\hline A. selago & - & - & + & - \\
\hline A. donei & - & - & + & - \\
\hline A. dendrum & - & - & + & + \\
\hline A. yongei & - & + & - & + \\
\hline A. hyacinthus & - & - & + & - \\
\hline A. lutkeni & + & + & + & - \\
\hline A. longicyathus & - & + & - & + \\
\hline Astreopora myriophthalma & + & - & + & - \\
\hline \multicolumn{5}{|l|}{ III. PORITIDAE } \\
\hline Porites. lobata & + & + & + & + \\
\hline P. lutea & + & + & + & + \\
\hline P. cylindrica & - & - & + & - \\
\hline P. nigrecens & + & + & + & + \\
\hline P. annae & + & + & + & - \\
\hline P. rus & - & + & + & - \\
\hline Goniopora djiboutiensis & - & - & + & + \\
\hline G. stokesi & - & + & + & - \\
\hline G. pendulus & - & - & + & - \\
\hline G. columna & - & + & + & - \\
\hline \multicolumn{5}{|l|}{ IV. SIDERASTREIDAE } \\
\hline Coscinaraea exesa & - & + & + & - \\
\hline C. columna & - & + & + & - \\
\hline C. mcneilli & - & - & + & + \\
\hline \multicolumn{5}{|l|}{ V. AGARICIIDAE } \\
\hline Pavona explanulata & - & - & + & + \\
\hline P. varians & - & - & + & - \\
\hline$P$. venosa & - & + & + & + \\
\hline Leptoseris. explanata & - & - & + & - \\
\hline L. mycetoseroides & - & - & + & - \\
\hline Gardineroseris planulata & - & - & + & - \\
\hline Pachyseris rugosa & - & - & + & + \\
\hline P. speciosa & - & - & + & - \\
\hline \multicolumn{5}{|l|}{ VI. FUNGIIDAE } \\
\hline Fungia danai & + & + & + & + \\
\hline F. scutaria & + & - & - & - \\
\hline Ctenactis simplex & - & - & + & + \\
\hline Halomitra pileus & - & - & + & + \\
\hline \multicolumn{5}{|l|}{ VII. OCULINIDAE } \\
\hline Galaxtrea astreata & - & + & + & + \\
\hline Archellia horrescens & - & + & + & - \\
\hline \multicolumn{5}{|l|}{ VIII. PECTINIDAE } \\
\hline Oxypora lacera & - & - & + & + \\
\hline O. glabra & - & - & + & - \\
\hline Mycedium elephantotus & - & - & + & + \\
\hline Pectinia lactuca & - & - & + & + \\
\hline \multicolumn{5}{|l|}{ IX. MUSSIDAE } \\
\hline Acanthastrea. lordhowensis & - & - & + & + \\
\hline A. hillae & - & + & + & - \\
\hline Lobophyllia hemprichii & - & - & + & + \\
\hline
\end{tabular}




\begin{tabular}{|c|c|c|c|c|}
\hline \multirow{2}{*}{ Suku / Jenis Karang Batu } & \multicolumn{4}{|c|}{ Lokasi Pengamatan } \\
\hline & Stasiun 1 & Stasiun 2 & Stasiun 3 & Stasiun 4 \\
\hline L. hataii & - & - & + & - \\
\hline Symphyllia recta & + & + & + & + \\
\hline S. wilsoni & - & - & + & - \\
\hline S. radians & - & + & + & - \\
\hline \multicolumn{5}{|l|}{ X. MERULINIDAE } \\
\hline Hydnophora rigida & + & + & + & + \\
\hline H. pilosa & - & - & + & - \\
\hline H. exesa & - & - & + & - \\
\hline \multicolumn{5}{|l|}{ XI. FAVIIDAE } \\
\hline Favia stelligera & + & + & + & + \\
\hline F. speciosa & - & + & + & - \\
\hline F. matthaii & - & - & + & - \\
\hline F. maritima & + & - & + & - \\
\hline Favites abdita & + & + & + & + \\
\hline F. halicora & - & - & + & - \\
\hline F. complanata & - & + & + & - \\
\hline Goniastrea retiformis & + & + & + & - \\
\hline G. aspera & + & + & + & + \\
\hline G. favulus & + & - & - & - \\
\hline G. pectinata & - & - & + & - \\
\hline Platygyra daedalae & - & - & + & - \\
\hline P. lamellina & - & + & - & + \\
\hline P. pinii & - & - & + & - \\
\hline Leptoria phyrygia & - & - & + & - \\
\hline Oulophyllia crispa & - & + & - & - \\
\hline O. bennettae & - & - & + & - \\
\hline Montastrea curta & + & + & + & - \\
\hline M. annuligera & - & - & + & - \\
\hline M. valenciennesi & - & - & + & + \\
\hline Diploastrea heliopora & - & + & + & - \\
\hline Leptastrea inaequalis & - & - & + & - \\
\hline Cyphastrea microphthalma & - & + & + & + \\
\hline Echinopora lamellosa & + & + & + & + \\
\hline E. gemmacea & - & - & + & - \\
\hline E. horrida & - & + & + & - \\
\hline \multicolumn{5}{|l|}{ XII. CARYOPHYLLIDAE } \\
\hline Euphyllia glabrescens & - & - & + & + \\
\hline E. ancora & + & - & + & - \\
\hline \multicolumn{5}{|l|}{ XIII. DENDROPHYLLIDAE } \\
\hline Turbinaria mesenterina & - & - & + & + \\
\hline Tubastrea micrantha & - & - & + & - \\
\hline \multicolumn{5}{|l|}{ XIV. HELIOPORIDAE } \\
\hline Heliopora coerulea & + & - & - & + \\
\hline Jenis & 27 & 43 & 89 & 41 \\
\hline Marga & 16 & 24 & 38 & 31 \\
\hline Suku & 8 & 10 & 13 & 14 \\
\hline
\end{tabular}

Keterangan : $+=$ ada

$$
\text { - = tidak ada }
$$




\section{Kondisi Karang Batu}

Persentase tutupan karang batu (Tabel 2) tertinggi dijumpai pada lokasi Stasiun 3 sebesar $53,44 \%$ terendah dijumpai di Stasiun 1 dengan persentase tutupan sebesar 1\%. Komponen karang mati beralgae (DCA) dengan persentase tutupan tertinggi dijumpai di Stasiun 2 sebesar $38,96 \%$ dan terendah dijumpai di Stasiun 4 dengan persentase tutupan $28,82 \%$. Soft coral (SC) dengan persentase tutupan tertinggi ditemukan di stasiun 1 dengan nilai 36,60\% dan terendah di Stasiun 4 yang tidak ditemukan SC. Patahan karang (R) ditemukan di semua stasiun pengamatan sedangkan komponen pasir (S) ditemukan hanya di Stasiun 1 dan 2. Komponen pasir halus (SI) dan batuan keras (RCK) tidak ditemukan di semua stasiun.

Besarnya nilai persentase tutupan karang batu yang diperoleh di perairan Kecamatan Wori bila dikategorikan berdasarkan tingkat kemantapan terumbu karang yang di kemukakan oleh Gomez dan Alcala (1978) yaitu persentase tutupan karang antara; 0-24,9 masuk kategori jelek, 25-49,9\% masuk kategori sedang, 50-74,9\% masuk kategori baik dan $75-100 \%$ masuk kategori sangat baik. Dengan demikian, dari persentase tutupan yang diperoleh pada pengamatan di perairan Kecamatan Wori menunjukkan bahwa kondisi karang hidup di lokasi ini berada dalam kategori jelek sampai baik $(1 \%-53,44 \%)$ dengan nilai rerata persentase tutupan karang hidup sebesar $31,80 \%$ dan termasuk dalam kategori sedang. Jika dibandingkan dengan nilai persentase tutupan yang diperoleh Souhoka (2004) diperairan Selat Lembeh Bitung $(72,17 \%)$ dan diperairan Tanjung Merah Sulawesi Utara yaitu $73,44 \%$ (Souhoka, 2007) ternyata nilai persentase tutupan karang hidup di perairan Kecamatan Wori lebih kecil. Sebaliknya nilai persentase tutupan karang hidup di Kecamatan Wori lebih besar bila dibandingkan dengan yang ditemukan Manuputty (2007) di perairan Tapanuli Tengah (Hajoran) sebesar 48,47\%, dan di perairan Selayar Sulawesi Selatan sebesar 48,3\% (Manuputty, 2007).

Kecilnya nilai persentase tutupan karang batu di perairan Kecamatan Wori disebabkan oleh beberapa faktor antara lain adanya penangkapan ikan dengan menggunakan bom, potasium sianida (potas) dan pukat dasar yang dioperasikan dengan cara melingkari koloni karang. Di samping itu dijumpai Acanthaster plancii yang merupakan salah satu organisme pemakan polip karang di Stasiun 1 sebanyak 10 ekor, Stasiun 3 sebanyak 5 ekor dan Stasiun 4 sebanyak 7 ekor. Khususnya untuk Stasiun 1, kecilnya persentase tutupan karang batu di lokasi ini karena lokasi ini dekat dengan sebuah sungai, sehingga pada saat penghujan air sungai meluap dan masuk sampai ke daerah terumbu karang sehingga dapat menurunkan salinitas perairan yang menyebabkan kematian karang batu.

Tabel 2. Persentase tutupan komponen ekosistem terumbu karang pada lokasi penelitian di Kecamatan Wori, April 2008.

\begin{tabular}{lccccc}
\hline \multirow{2}{*}{ Komponen } & \multicolumn{4}{c}{ Stasiun Pengamatan } \\
\cline { 3 - 6 } & & $\mathbf{1}$ & $\mathbf{2}$ & $\mathbf{3}$ & $\mathbf{4}$ \\
\hline \hline Karang hidup & (LC) & 1,00 & 24,56 & 53,44 & 48,18 \\
Karang mati & (DC) & 0,00 & 0,00 & 0 & 0 \\
Karang mati beralge & (DCA) & 31,46 & 38,96 & 31,14 & 28,82 \\
Karang lunak & (SC) & 36,60 & 14,36 & 6,9 & 0 \\
Fauna lain & (OT) & 2,30 & 2,74 & 1,24 & 7,9 \\
Sponges & (SP) & 12,20 & 1,30 & 5,32 & 0 \\
Algae & (FS) & 0,00 & 0,00 & 0 & 1 \\
Patahan karang & (.R) & 0,52 & 16,08 & 1,96 & 14,1 \\
Pasir & (S) & 15,92 & 2,00 & 0 & 0 \\
Pasir halus & (SI) & 0,00 & 0,00 & 0 & 0 \\
Batuan keras & (RCK) & 0,00 & 0,00 & 0 & 0 \\
\hline \hline
\end{tabular}


Jumlah koloni jenis karang batu dan komponen lainnya (Tabel 3) yang diperoleh pada garis transek sebanyak 471 komponen yang terdiri atas karang batu sebanyak 172 koloni yaitu Acropora 21 koloni dan non-Acropora 151 koloni. Komponen lain dijumpai sebanyak 299 komponen, dengan jumlah terbanyak dijumpai di Stasiun 2 sebanyak 103 komponen yang didominasi oleh karang mati beralge (DCA) sebanyak 47 komponen. Karang batu marga Acropora yang mempunyai jumlah koloni tertinggi adalah Acropora yongei yaitu sebanyak 10 koloni, dijumpai di Stasiun 4. Koloni karang non-Acropora yang tertinggi adalah jenis Porites nigrecens, yaitu sebanyak 33 koloni, dijumpai di Stasiun 3. Kehadiran jenis Acropora yongei di Stasiun 4 disebabkan kondisi perairan lokasi ini agak tenang. Hal ini sejalan dengan pendapat Suharsono (2008) yang menyatakan bahwa karang batu jenis Acropora yongei umumnya dijumpai hidup di tempat yang dangkal, dan relatif tenang dan koloni ini dapat mencapai ukuran besar atau dapat mendominasi pertumbuhan karang di suatu daerah tertentu. Demikian juga dengan Porites nigrecens, jenis ini tersebar di seluruh perairan Indonesia dan biasanya ditemukan di daerah rataan terumbu sampai di daerah tubir, dan pada lokasi yang masih baik jenis ini sangat melimpah (Suharsono, 2008).

Total panjang koloni komponen bentik yang diteliti sangat bervariasi dengan ukuran berkisar antara 10-6519 cm. Acropora yongei memiliki panjang koloni yang terpanjang yaitu $1,769 \mathrm{~cm}$ yang dijumpai di Stasiun 4, sebaliknya yang terpendek adalah Acropora palifera sebesar $10 \mathrm{~cm}$ yang dijumpai di Stasiun 3 .

Karang batu non-Acropora koloni terpanjang adalah jenis Porites nigrecens dengan panjang $1448 \mathrm{~cm}$ dan yang terpendek Fungia $s p$ sebesar $5 \mathrm{~cm}$ yang ditemukan di Stasiun 3 . Komponen lain lebih didominasi oleh karang mati beralge (DCA) dengan panjang $1.948 \mathrm{~cm}$ yang ditemukan di Stasiun 2 (Tabel 4).

Panjang koloni tiap jenis karang batu berkaitan dengan kemampuan karang batu dalam berkompetisi untuk menempati ruang yang lebih besar. Karang batu memiliki sifat agresi jika koloni mengalami kompetisi terhadap ruang melalui pertumbuhan yang lebih besar dan lebih cepat daripada yang lainnya. Koloni masif yang mempunyai pertumbuhan lambat sangat mudah ditimpa, tetapi mereka tidak mudah rusak oleh serangan badai atau organisme pelubang. Sebaliknya marga Acropora biasanya mudah rusak oleh siklon atau bulu seribu (Acanthaster plancii) (Sudiarta, 1995).

Hasil analisis keanekaragaman jenis $(\mathrm{H})$ dan kemerataan jenis (j) sebagaimana ditampilkan dalam Gambar 6, menunjukkan nilai keanekaragaman jenis karang batu tertinggi dijumpai di Stasiun 3 sebesar 1,06 dan terendah di Stasiun 1 dengan nilai 0,84 . Besarnya nilai keanekaragaman jenis karang batu di Stasiun 3 menunjukkan bahwa jenis karang batu di lokasi ini cukup beragam atau mempunyai jumlah jenis yang terbanyak dibandingkan dengan stasiun yang lain dan tidak didominasi oleh jenis tertentu. Jika dibandingkan dengan nilai keanekaragaman jenis yang ditemukan Souhoka (2002) di daerah Batuangus Bitung $(2,20)$ ternyata nilai ini lebih kecil. Walaupun nilai indeks keanekaragaman lokasi ini kecil, kondisi karang batu di lokasi ini tergolong produktif sampai sangat produktif berdasarkan kriteria yang ditentukan oleh Stodart dan Johnson dalam Mauputty (1990) sebagaimana tercantum dalam Tabel 5.

Berdasarkan hasil uji indeks kemerataan (Gambar 6) menunjukkan bahwa nilai tertinggi dijumpai di Stasiun 4 sebesar 0,56 dan terendah di Stasiun 1 sebesar 0,42. Besarnya nilai indeks kemerataan di Stasiun 4 menggambarkan bahwa sebaran jenis karang batu pada lokasi ini merata, tidak berkelompok atau berupa paches-paches kecil. Sebaliknya di Stasiun 1 ada kecenderungan didominasi oleh jenis tertentu yaitu karang non-Acropora seperti Fungia sp, Oulophyylia sp dan Montipora hoffmeisteri. Keberadaan jenis karang Montipora hoffmeisteri biasanya ditemukan pada lokasi yang tenang dan kecerahan air agak rendah. 
Tabel 3. Jumlah koloni jenis karang batu dan komponen lain pada lokasi penelitian di perairan Kecamatan Wori, April 2008.

\begin{tabular}{|c|c|c|c|c|c|c|}
\hline \multirow[t]{2}{*}{ No. } & \multirow{2}{*}{$\begin{array}{c}\text { Komponen Bentik } \\
\text { Karang Batu }\end{array}$} & \multicolumn{4}{|c|}{ Jumlah Koloni } & \multirow[t]{2}{*}{ Total Koloni } \\
\hline & & 1 & 2 & 3 & 4 & \\
\hline & Acropora & & & & & \\
\hline 1 & Acropora yongei & 0 & 0 & 0 & 10 & 10 \\
\hline 2 & Acropora sp & 0 & 0 & 1 & 0 & 1 \\
\hline 3 & Acropora clathrata & 0 & 0 & 1 & 1 & 2 \\
\hline 4 & $\begin{array}{l}\text { Acropora palifera } \\
\text { Non-Acropora }\end{array}$ & 0 & 7 & 1 & 0 & 8 \\
\hline 5 & Porites nigrecens & 0 & 21 & 33 & 0 & 54 \\
\hline 6 & Porites rus & 0 & 0 & 0 & 0 & 0 \\
\hline 7 & Porites lutea & 0 & 2 & 0 & 0 & 2 \\
\hline 8 & Porites lobata & 0 & 9 & 9 & 0 & 18 \\
\hline 9 & Galaxtrea astreata & 0 & 0 & 6 & 2 & 8 \\
\hline 10 & Echinopora lamellosa & 0 & 0 & 1 & 1 & 2 \\
\hline 11 & Favites abdita & 0 & 0 & 1 & 0 & 1 \\
\hline 12 & Favites sp & 0 & 2 & 12 & 1 & 15 \\
\hline 13 & Fungia $s p$ & 1 & 2 & 1 & 1 & 5 \\
\hline 14 & Pocillopora verrucosa & 0 & 0 & 1 & 0 & 1 \\
\hline 15 & Goniastrea $s p$ & 0 & 0 & 1 & 0 & 1 \\
\hline 16 & Seriatophora caliendrum & 0 & 0 & 2 & 1 & 3 \\
\hline 17 & Montipora hoffmeisteri & 1 & 0 & 3 & 0 & 4 \\
\hline 18 & Montipora undata & 0 & 0 & 0 & 2 & 2 \\
\hline 19 & Montipora sp & 0 & 1 & 2 & 2 & 5 \\
\hline 20 & Oulophyllia $s p$ & 1 & 1 & 0 & 0 & 2 \\
\hline 21 & Pectinia lactuca & 0 & 0 & 6 & 2 & 8 \\
\hline 22 & Favia $s p$ & 0 & 0 & 1 & 0 & 1 \\
\hline 23 & Hidnophora rigida & 0 & 4 & 2 & 0 & 6 \\
\hline 24 & Heliopora coerulea & 0 & 8 & 0 & 0 & 8 \\
\hline 25 & Millepora $s p$ & 0 & 3 & 1 & 0 & 4 \\
\hline 26 & $\begin{array}{l}\text { Montipora crassituberculata } \\
\text { Komponen lain }\end{array}$ & 0 & 0 & 1 & 0 & 1 \\
\hline 27 & DCA & 33 & 47 & 47 & 15 & 142 \\
\hline 28 & SC (Sinularia sp) & 21 & 21 & 7 & 0 & 49 \\
\hline 29 & $\mathrm{SC}($ Sarcophyton $\mathrm{sp})$ & 2 & 10 & 8 & 0 & 20 \\
\hline 30 & $\mathrm{R}$ & 2 & 13 & 1 & 2 & 18 \\
\hline 31 & $\mathrm{~S}$ & 13 & 3 & 0 & 0 & 16 \\
\hline 32 & SP & 4 & 5 & 4 & 4 & 17 \\
\hline 33 & OT & 4 & 4 & 12 & 0 & 20 \\
\hline 34 & MA (Markroalgae) & 6 & 0 & 0 & 1 & 7 \\
\hline 35 & HA (Halimeda sp) & 10 & 0 & 0 & 0 & 10 \\
\hline & Total & 98 & 163 & 165 & $\overline{445}$ & 471 \\
\hline
\end{tabular}

Keterangan: 1, 2, 3 dan 4 adalah stasiun pengamatan. 
Tabel 4. Panjang koloni jenis karang batu dan komponen lain pada lokasi penelitian di perairan Kecamatan Wori, April 2008.

\begin{tabular}{|c|c|c|c|c|c|c|}
\hline \multirow[t]{2}{*}{ No } & \multirow{2}{*}{$\begin{array}{c}\text { Komponen Bentik } \\
\text { Karang Batu }\end{array}$} & \multicolumn{4}{|c|}{ Panjang Koloni (cm) } & \multirow{2}{*}{$\begin{array}{c}\text { Total Panjang } \\
\text { Koloni }\end{array}$} \\
\hline & & 1 & 2 & $\mathbf{3}$ & 4 & \\
\hline & Acropora & & & & & \\
\hline 1 & Acropora yongei & 0 & 0 & 0 & 1769 & 1769 \\
\hline 2 & Acropora sp & 0 & 0 & 30 & 0 & 30 \\
\hline 3 & Acropora clathrata & 0 & 0 & 50 & 25 & 75 \\
\hline 4 & $\begin{array}{l}\text { Acropora palifera } \\
\text { Non-Acronora }\end{array}$ & 0 & 123 & 10 & 0 & 133 \\
\hline 5 & Porites nigrecens & 0 & 405 & 1448 & 0 & 1853 \\
\hline 6 & Porites rus & 0 & 0 & 0 & 0 & 0 \\
\hline 7 & Porites lutea & 0 & 57 & 0 & 0 & 57 \\
\hline 8 & Porites lobata & 0 & 185 & 203 & 0 & 388 \\
\hline 9 & Galaxtrea astreata & 0 & 0 & 70 & 95 & 165 \\
\hline 10 & Echinopora lamellosa & 0 & 0 & 80 & 180 & 260 \\
\hline 11 & Favites abdita & 0 & 0 & 20 & 0 & 20 \\
\hline 12 & Favites sp & 0 & 33 & 208 & 20 & 261 \\
\hline 13 & Fungia $s p$ & 20 & 23 & 5 & 20 & 68 \\
\hline 14 & Pocillopora verrucosa & 0 & 0 & 10 & 0 & 10 \\
\hline 15 & Goniastrea $s p$ & 0 & 0 & 40 & 0 & 40 \\
\hline 16 & Seriatophora caliendrum & 0 & 0 & 55 & 60 & 115 \\
\hline 17 & Montipora hoffmeisteri & 10 & 0 & 155 & 0 & 165 \\
\hline 18 & Montipora undata & 0 & 0 & 0 & 65 & 65 \\
\hline 19 & Montipora $s p$ & 0 & 12 & 34 & 85 & 131 \\
\hline 20 & Oulophyllia $s p$ & 20 & 37 & 0 & 0 & 57 \\
\hline 21 & Pectinia lactuca & 0 & 0 & 159 & 90 & 249 \\
\hline 22 & Favia $s p$ & 0 & 0 & 25 & 0 & 25 \\
\hline 23 & Hidnophora rigida & 0 & 79 & 40 & 0 & 119 \\
\hline 24 & Heliopora coerulea & 0 & 214 & 0 & 0 & 214 \\
\hline 25 & Millepora sp & 0 & 60 & 20 & 0 & 80 \\
\hline 26 & $\begin{array}{l}\text { Montipora crassituberculata } \\
\text { Komponen lain }\end{array}$ & 0 & 0 & 10 & 0 & 10 \\
\hline 27 & DCA & 1573 & 1948 & 1557 & 1441 & 6519 \\
\hline 28 & SC (Sinularia sp) & 1720 & 465 & 157 & 0 & 2342 \\
\hline 29 & $\mathrm{SC}($ Sarcophyton $\mathrm{sp})$ & 55 & 253 & 188 & 0 & 496 \\
\hline 30 & $\mathrm{R}$ & 26 & 804 & 98 & 705 & 1633 \\
\hline 31 & $S$ & 796 & 100 & 0 & 0 & 896 \\
\hline 32 & SP & 115 & 137 & 62 & 395 & 709 \\
\hline 33 & OT & 61 & 65 & 266 & 0 & 392 \\
\hline 34 & MA (Markroalgae) & 329 & 0 & 0 & 50 & 379 \\
\hline \multirow[t]{2}{*}{35} & HA (Halimeda sp) & 275 & 0 & 0 & 0 & 275 \\
\hline & Total & 5000 & 5000 & 5000 & 5000 & 20000 \\
\hline
\end{tabular}

Keterangan: 1, 2, 3 dan 4 adalah stasiun pengamatan.

Tabel 5. Kriteria produktivitas terumbu karang berdasarkan nilai indeks keanekaragaman jenis (Stodart dan Johnson dalam Manuputty, 1990).

\begin{tabular}{|c|c|}
\hline Indeks Keanekaragaman Jenis (H) & Kriteria \\
\hline $0,00-0,25$ & tidak produktif \\
\hline $0,25-0,50$ & kurang produktif \\
\hline $0,50-0,75$ & sedikit produktif \\
\hline $0,75-1,00$ & produktif \\
\hline 1 & sangat produktif \\
\hline
\end{tabular}




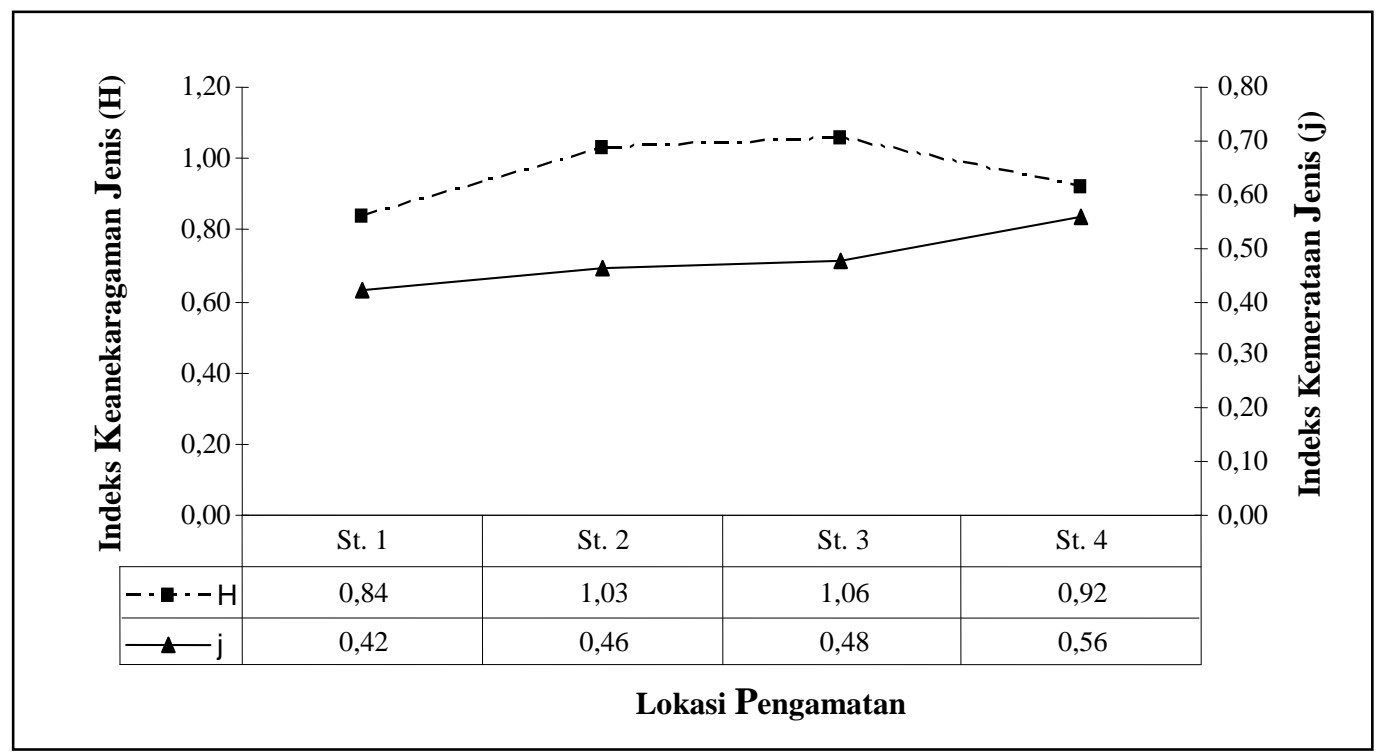

Gambar 6. Indeks keanekaragaman jenis (H) dan Indeks kemerataan jenis (j) karang batu pada lokasi penelitian di perairan Kecamatan Wori, April 2008.

\section{Simpulan dan Saran}

\section{Simpulan}

Karang batu yang ditemukan di perairan Kecamatan Wori sebanyak 99 jenis yang termasuk dalam 40 marga dan 14 suku. Rataan terumbu di perairan Kecamatan Wori mempunyai panjang yang bervariasi dari 175-225 meter. Karang batu di lokasi Wori umumnya hidup terkonsentrasi pada bentuk dasar yang agak miring sampai curam dengan kedalaman air diatas $20 \mathrm{~m}$. Kondisi karang batu dan komponen lainnya berkisar antara $1-52,44 \%$ dan termasuk dalam kategori jelek sampai baik. Komponen lain didominasi oleh karang mati beralgae dan patahan karang dan pasir.

\section{Saran}

Dari hasil yang diperoleh di atas, maka dapat diberikan beberapa saran sebagai berikut: hasil pengamatan keseluruhan menunjukkan kondisi karang batu yang bervariasi sehingga untuk lebih meningkatkan kondisi karang batu agar lebih baik, perlu dilakukan usaha pencegahan dari kerusakan oleh manusia secara intensif. Sosialisasi tentang pentingnya ekosistem terumbu karang perlu ditingkatkan lagi sebagai bahan informasi bagi masyarakat.

\section{Ucapan Terima Kasih}

Penulis menyampaikan banyak terima kasih kepada Bapak Drs. E. Yusron M.Si selaku kordinator penelitian Biodiversitas perairan Kecamatan Wori, yang telah memberikan kesempatan kepada penulis untuk melakukan pengambilan data karang batu di perairan Kecamatan Wori, Sulawesi Utara. Saudara Simon Patty yang telah membantu membuat peta lokasi penelitian dan juga kepada teman-teman di UPT. Loka Konservasi Biota Laut - LIPI Bitung yang telah membantu pekerjaan selama di lapangan.

\section{Daftar Pustaka}

Allen, G.R. dan Steene, R. 2002. Indo - Pasific. Coral Reef. Field Guide.

Ditlev, H. 1980. A field-guide to the Reef-building coral of the Indo-Pasific. Scandinavian Science Press Ltd. Klampenborg.

Den Hartog, S. 1970. The Sea - Grasses of the World. North Holland Publishing Company - Amsterdam, London.

English, S., Wilkinson, C. dan Baker, V. 1997. Survey Manual for Tropical Marine Resources. Second Edition. Australian Institute of Marine Science. Townsville. 
Gomez, E.D. dan Alcala, A.C. 1978. Stastus of Philiphina Coral Reef. Project, Int. Symp. Biogeogr. Evol. S. Hem. Auckland New Zealand, 17 - 20 July 1978. 2: 663-669.

Koh, E.G.I. dan Chou, L.M. 1989. The Mushroom Corals Of Singapore. Reef Ecology Study Team. Departement of Zoology, National University of Singapore, Singapore.

Manuputty, A.E.W. 1990. Sebaran, Keanekaragaman dan Komposisi Jenis Karang Batu di Perairan Kabil. In: Soemodihardjo, S., Birowo, S. dan Romimohtarto, K. (Eds.). Perairan Pulau Batam. Hal: 15-23. Pusat Penelitian dan Pengembangan Oseanografi - LIPI, Jakarta.

Manuputty, A.E.W. 2007a. Baseline Ekologi, Tapanuli Tengah (Hajoran). Coral Reef Rehabilitation and Management Program II - LIPI, Jakarta.

Manuputty, A.E.W. 2007b. Monitoring Ekologi Selayar. Coral Reef Rehabilitation and Management Program, Lembaga Ilmu Pengetahuan Indonesia. COREMAP II - LIPI, Jakarta.

Moll, H. dan Moka, W. 1986. Indonesia - Deutch SnelliusII Expedition. Compedium 4. Guide to Indonesia Reef Corals.

Odum, E.P. 1971. Fundamental of Ecology. W.E. Sunders, Philadelphia.

Pielou. 1966. The Measurement of Diversity in Different Types of Biological Collections. J. Theor. Biol, 13: $131-144$

Salm, R.V. dan Clark, J.R. 1989. Marine and Coastal Protected Areas; A guide for planner and managers. International Union for Conservation of Nature and Natural Resources. Gland, Switzerland.
Sudiarta, I.K. 1995. Struktur Komunitas Ekosistem Terumbu Karang dan Pemintakatan Kawasan Wisata Bahari Pulau Lembongan, Bali. Program Pascasarjana. Institut Pertanian Bogor.

Suharsono. 2008. Jenis-Jenis Karang di Indonesia. Lembaga Ilmu Pengetahuan Indonesia. COREMAP PROGRAM, Jakarta.

Sukarno, Hutomo, M., Moosa, M.K. dan Darsono, P. 1981. Terumbu Karang di Indonesia. Sumberdaya, Permasalahan dan Pengelolaannya. Proyek Penelitian Potensi Sumberdaya Alam Indonesia. Lembaga Oseanologi Nasional, Lembaga Ilmu Pengetahuan Indonesia, Jakarta.

Souhoka, J. 2004. Kondisi Terumbu Karang di Perairan Selat Lembeh, Sulawesi Utara. Oseanologi dan Limnologi di Indonesia, 36 (36): 33-50.

Souhoka, J. 2007. Sebaran dan Kondisi Karang Batu (Hard Coral) di Perairan Tanjung Merah Bitung, Sulawesi Utara. Oseanologi dan Limnologi di Indonesia, 33 (33): 393-411.

Souhoka, J. 2002. Keanekaragaman Jenis dan Kondisi Karang Batu di Beberapa Lokasi Perairan Pesisir Utara Sulawesi Utara. In: Ruyitno, A., Aziz dan Pramudji (Eds.). Perairan Sulawesi dan Sekitarnya, Biology, Lingkungan dan Oseanografi. Hal: 121-129. Pusat Penelitian Oseanografi dan Pusat Penelitian Limnologi LIPI, Jakarta.

UNEP. 1993. Monitoring Coral reefs for global change. Reference Methods for Marine Pollution Studies No. 61.

Veron, J.E.N. 1986. Coral of Australian and Indo-Pasific. Australian Institute of Marine Science, Townsville. 